\title{
Causes of land-bird extinctions in French Polynesia
}

\author{
Roland and Julia Seitre
}

During a 4-month study in French Polynesia, the authors visited 28 islands, seven of which had never been explored by ornithologists. They collected ecological data on endemic land birds, introduced animals and habitats, focusing particularly on the factors involved in population declines and extinctions. As well as hunting and habitat destruction, it appears that introduced predators play a major role, with the roof rat Rattus rattus being the most dangerous. Rapid action to eradicate introduced predators, coupled with translocations, would be the most effective way to ensure the survival of the remaining bird species.

French Polynesia is a galaxy of about 120 islands (atolls, elevated atolls and volcanic islets) dispersed over an area the size of Europe. A range of habitats provide refuge for many endemic species of birds, reptiles, freshwater fishes and invertebrates. Birds are the only large terrestrial vertebrates to have arrived from distant Australia and $\mathrm{New}$ Guinea. Of the 30 regularly occurring species, 15 (and 40 subspecies) are endemic (Thibault, 1988). All these endemics are considered threatened or endangered; the ICBP world check-list of threatened birds includes 14 of these (Collar and Andrew, 1988).

Tahiti, perhaps the most famous island in the South Pacific, is thought to be a natural paradise. However, while the scenery gives this impression, humans have caused drastic changes. For millions of years, evolution took place without herbivores, birds of prey, large reptiles and mammals. About 2000 years ago the Polynesians, after an extraordinary sailing odyssey, reached the Marquesas archipelago, from where they spread to Hawaii, Tahiti, Easter Island and New Zealand. They brought with them the first mammals - pigs, dogs, Polynesian rat Rattus exulans - and domestic chickens. Europeans came later. In 1521 Magellan, the first navigator to visit the region, apparently did not see any of the Tuamotu atolls, although he passed the archipelago. Then Mendana found the
Marquesas in 1595. In 1766, Wallis, the official discoverer of Tahiti, started the natural history records followed by those of Cook's expeditions in 1769, 1773 and 1777. Europeans introduced goats, sheep, cattle, horses, rabbits and domestic cats, as well as, unintentionally, roof rats Rattus rattus, brown rats Rattus norvegicus and house mice Mus musculus. Various birds came much later. All these introductions were certainly not documented, although we know that Cook's vessels liberated roof rats in New Zealand (Sparrman, 1953). Although officially the third European to reach Tahiti, Cook recorded that at least two vessels had anchored there and in Raiatea before Wallis, so introductions of European pests could have been earlier than is generally believed and could partly explain why at least five native species were never seen again after Cook's passage, although they had survived 1000 years of Polynesian presence. Only one species, the Marquesas fruit dove Ptilinopus mercierii, has become extinct during the twentieth century, but many other bird species have suffered range reductions and their current status is very poorly known.

\section{The 1989-1990 investigation}

During 4 months in 1989 and 1990, we surveyed 28 islands, seven of which had never 
been explored by ornithologists, to collect ecological data and analyse bird extinctions (Figure 1). Our visits ranged from a few hours to a maximum of 4 days per island and we were able to collect enough data to make valid comparisons in most cases. When species were present in these island ecosystems, they were usually very common and easily heard or seen. Traps were set for rodents, but rats were also quite frequently observed during daytime, especially on atolls. The final aim was, after determining the major causes of extinction of the indigenous landbirds, to propose some specific conservation measures.

\section{Major causes of bird extinctions}

The information for each island was summarized in tables, which included bibliographical information where this was available. The tables were used to compare the status of

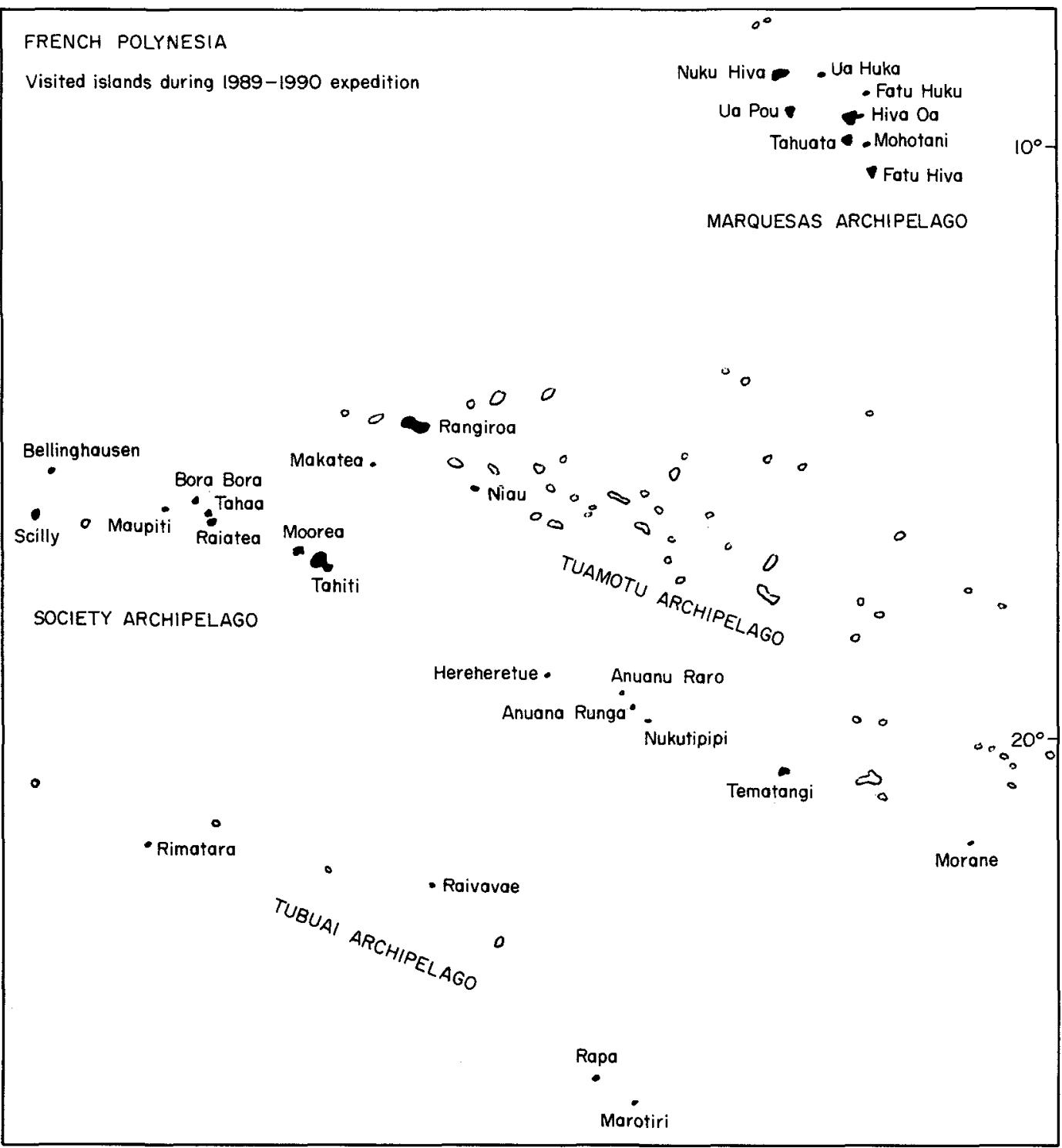

Figure 1. Islands visited during the 1989-1990 expedition. 


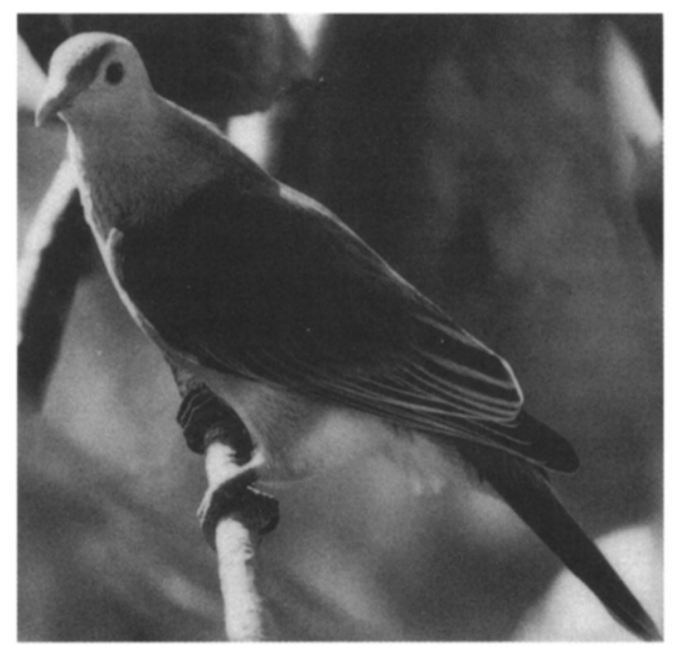

Ptilinopus purpuratus chalcurus, the Makatea subspecies of a widespread fruit dove (Roland Seitre).

native bird species with ecological factors, including the presence and absence of introduced species, in an attempt to determine the most probable causes of declines and extinctions in native bird populations.

\section{Hunting}

Hunting is a direct threat to the survival of very rare Marquesas pigeon Ducula galeata on Nuku Hiva, its only remaining location. Bone remains found by Steadman (1989) on Ua Huka, Hiva Oa, Tahuata (all in the Marquesas), Huahine (Society Islands), Mangaia (Cook Islands), and Henderson Island (Pitcairn group), suggest that hunting was the cause of extirpation on other islands during Polynesian times.

\section{Habitat destruction}

Habitat destruction is the obvious cause of the decline of the Rapa Island fruit dove Ptilinopus huttoni, which is endemic to Rapa. Due to the effects of fires and herbivores only very small patches of indigenous forest remain in gullies, where the birds are, in fact, very common. Thibault and Varney (1991) recommended a number of conservation measures to the local authorities, including fencing the largest part of the Hiti Valley forest.
The possible extinction of the Society Islands pigeon Ducula aurorae from Tahiti, where it was last recorded in 1973 (Holyoak and Thibault, 1984) could be due to a combination of factors. Hunting may have caused the species to retreat into the interior of the island, where the forest has been invaded by an introduced shrub Miconia magnifica from tropical America. Reduction of habitat by phosphate mining on Makatea atoll, the only other known site for this species, was a threat but mining ceased 30 years ago and, although forest regeneration is very slow, pigeon numbers are stable or increasing.

Drainage of wetlands reduced habitat for sooty crake Porzana tabuensis and Polynesian duck Anas poecilorhyncha superciliosa (Thibault, 1973).

\section{Bird predation}

Comparing the situation on relatively similar islands showed that the introduced mynah Acridotheres tristis can have a direct impact on Collocalia spp. (Table 1). This supported the claim by Holyoak and Thibault (1984) about Collocalia declines. Mynahs are known to predate the eggs of cave swiftlets Collocalia spp.

In addition, Nuku Hiva and Hiva Oa, the two largest islands of the Marquesas, have quite similar conditions. The first island still has four common indigenous species, the second has scarcely any birds left (one Acrocephalus sp. seen in $48 \mathrm{~h}$ ). The difference between these two islands is attributable to the presence of the great horned owl Bubo virginianus, which was introduced in the 1930s on Hiva $\mathrm{Oa}$ and is now well established. The endemic species had never been subject to nocturnal predation and appeared unable to adapt to it. Fortunately, this is the only case of such an introduction for the whole region.

\section{Cat predation}

Feral cats contributed to the extinction of many species and they may be the direct cause of extirpation of ground doves Gallicolumba spp. on many islands.

We lack data on the Society Islands ground 
Table 1. The occurrence of mynahs and Collocalia spp. on various islands in French Polynesia

\begin{tabular}{lcccccc}
\hline Species & Tahiti & Moorea & Hiva Oa & Nuku Hiva Ua Pou & Ua Huka \\
\hline $\begin{array}{l}\text { Cave swiftlets } \\
\text { Collocalia spp. }\end{array}$ & $-\left(^{*}\right)$ & $-\left(^{*}\right)$ & - & + & + & + \\
Acridotheres tristis & + & + & + & 0 & 0 & 0 \\
\hline
\end{tabular}

+ , abundant; - rare; 0 , absent (or extinct when native birds); ${ }^{*}$ ), literature.

dove Gallicolumba erythroptera, which probably survives on some isolated islets in the Tuamotu archipelago. Gallicolumba rubescens, a Marquesas endemic, was historically known from Nuku Hiva and two small islets devoid of European rats or cats: Hatutu (Thibault, 1989) and Fatu Huku (confirmed by our study). Subfossils are known from three other islets (Steadman, 1989), suggesting that the species was originally distributed throughout the entire group. It is absent from Mohotani, probably because of the presence of cats. The only rat species present on Mohotani is the Polynesian rat, which is evidently not a serious threat to this species because $G$. erythroptera lives on Hatutu and Fatu Huku where Polynesian rats thrive. Removing the cats from this uninhabited island could open the way for a reintroduction programme. European rats can certainly also extirpate this species, which nests close to the ground (the only nest ever found was in a rock crevice, but other members of the genus are known to nest on low branches (Goodwin and Gillmor, 1970)).

\section{Rat predation}

Rats are well-known predators of birds, especially on islands (Moors, 1983; Atkinson, 1985; Taylor, 1985; Fuller, 1987). But with four species of rat-like rodents present, we were

Table 2. Occurrence of lories Vini spp., roof rats and marsh harrier on various islands in French Polynesia

\begin{tabular}{lllllllll}
\hline Species & Tahiti & Bora Bora Rangiroa & $\begin{array}{l}\text { Rangiroa } \\
\text { S }\end{array}$ & Scilly & $\begin{array}{l}\text { Belling- } \\
\text { hausen }\end{array}$ & Makatea & Niau \\
\hline $\begin{array}{l}\text { Tahitian lory } \\
\text { Vini peruviana }\end{array}$ & 0 & 0 & 0 & + & + & + & 0 & 0 \\
$\begin{array}{l}\text { Roof rat } \\
\text { Rattus rattus }\end{array}$ & + & + & + & $?$ & 0 & 0 & + & $?$ \\
$\begin{array}{l}\text { Marsh harrier } \\
\begin{array}{l}\text { Circus aeruginosus } \\
\text { approximans }\end{array}\end{array}$ & + & + & 0 & 0 & 0 & 0 & 0 & 0 \\
& & & & & & & \\
\\
\end{tabular}

+ , abundant; -, rare; 0 , absent (or extinct when native birds)

(one roof rat was trapped by Y. Séchan on Ua Huka, pers. comm.) 


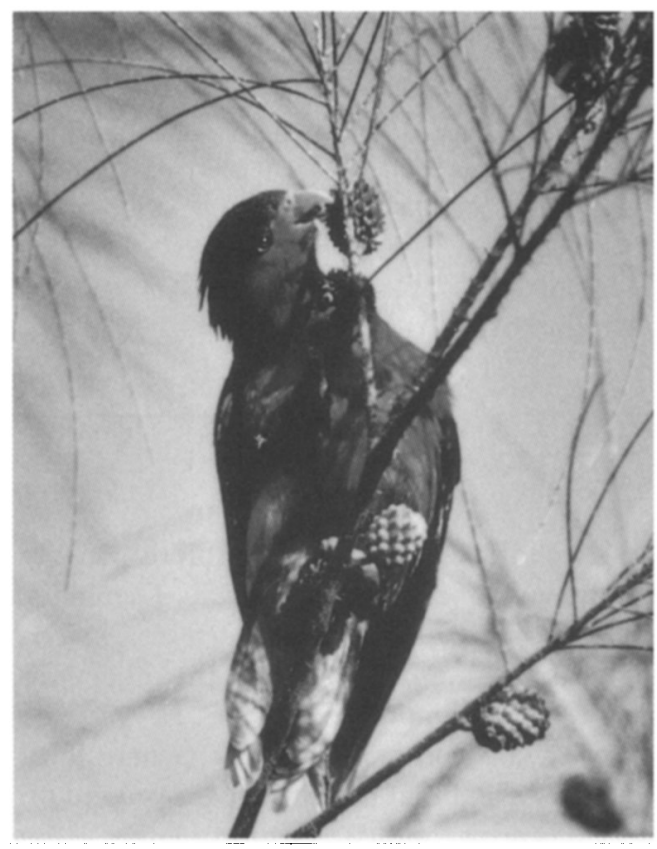

Kuhl's lory Vini kuhlii has a very restricted known original range: the island of Rimatara (Roland Seitre).

interested to discover the effects of different species.

Three species of Vini lories inhabit the four archipelagos of French Polynesia. It has often been suggested that the introduced marsh harrier Circus aeruginosus approximans is the main predator of these birds. Table 2 compares the distribution of lories with that of Rattus rattus and the marsh harrier.

Circus could have accelerated the extinction of Vini on the mountainous Society Islands but, as the birds have become extinct or are dwindling on islands where no Circus have ever occurred, it seems clear that Rattus rattus is the main danger.

Although Vini and Rattus coexist on some islands, it is probably only a temporary phenomenon. Rats proliferate in the lowlands where birds soon disappear, the remaining population being driven to higher altitudes (as has happened in Ua Pou). While this habitat is not optimal for rats they do invade it as their numbers increase and force the birds to extinction. In atolls, birds can survive for a long time on isolated islets (motus). For example, Rangiroa is only partly occupied by birds, and

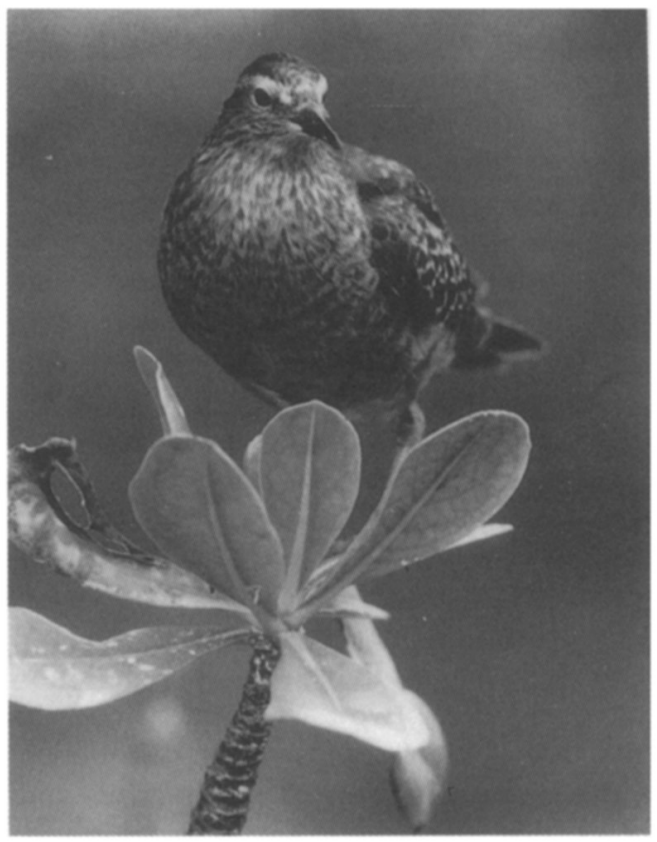

Prosobonia cancellata, the Tuamotu sandpiper might be threatened by Rattus exulans (Roland Seitre).

a similar situation occurs on Fanning Island further north in the Line Islands, where Kuhl's lory Vini kuhlii has been introduced and occupies one part of the atoll (Garnett, 1980), from which humans and other mammals are probably absent.

Rattus norvegicus has been trapped on Rimatara where Vini kuhlii commonly occurs, although local people say numbers have fallen. This rat is less arboreal than Rattus rattus and thus might not have as serious an effect on birds of the canopy, such as Vini lories.

The Tuamotu sandpiper Prosobonia cancella$t a$ is an atypical wader, its behaviour including foraging among the inflorescences of small trees. It has an extremely limited range on a few atoll islets (motus). Holyoak and Thibault (1984) considered predation by cats and roof or brown rats to be their limiting factors, but our observations in a previously unexplored group tend to prove that even the small Polynesian rat can be a significant predator for this species (Table 3). Prosobonia appears to be a relict species, which survived the arrival of Polynesians only because of the isolated and fragmented nature of its habitat, 
Table 3. The occurrence of the Tuamotu sandpiper and Polynesian rat on various islands in French Polynesia

\begin{tabular}{|c|c|c|c|c|c|c|}
\hline Species & Rangiroa & Morane & Nukutipipi & $\begin{array}{l}\text { Anuanu } \\
\text { Runga } 1 \\
\text { (large islet) }\end{array}$ & $\begin{array}{l}\text { Anuanu } \\
\text { Runga } 2 \\
\text { (small islet) }\end{array}$ & $\begin{array}{l}\text { Anuanu } \\
\text { Raro }\end{array}$ \\
\hline \multicolumn{7}{|l|}{ Tuamotu sandpiper } \\
\hline Prosobonia cancellata & $-\left(1^{*}\right)$ & + & 0 & 0 & + & 0 \\
\hline \multicolumn{7}{|l|}{ Polynesian rat } \\
\hline Rattus exulans & + & 0 & + & + & 0 & + \\
\hline
\end{tabular}

+ , abundant; - , rare; 0 , absent (or extinct when native birds); $\left({ }^{*}\right)$, literature.

which permitted some parts to remain free of introduced predators.

Flycatchers of the genus Pomarea are endemic to south-east Polynesia. Of the five surviving species, two are very close to extinction. Table 4 compares the distribution of the genus with that of Rattus rattus and shows that flycatchers are abundant only where rats are absent.

The situation is similar to that of the Vini lories, with some evidence of highland retreat when rats are present. These birds do not occur on atolls. Rattus rattus has been shown to be directly responsible for the decline of the endemic flycatcher $P$. dimidiata in Raratonga, Cook Islands (R. Hay, pers. comm.).

\section{Undetermined}

Tahiti swallow Hirundo tahitica numbers are decreasing, but no specific factor could be identified: habitat destruction, competition with and eventually predation by introduced bird species are all possible contributory factors. Kingfishers Halcyon spp. have survived quite well in Polynesia and are still reasonably common. We did not visit the Gambiers, where the subspecies Halcyon gambieri gambieri has disappeared, but we found the other subspecies of Tuamotu kingfisher $H$. gambieri gertrudae still common on Niau (where local people asserted that the bird is also present on other nearby atolls). Unfortunately, the Marquesas kingfisher Halcyon godeffroyi is almost extinct on Hiva Oa.

The super-species of long-billed warblers Acrocephalus caffra is very widespread in Polynesia, even on islets. Populations on different archipelagos have reacted very differently to the same factors, a paradox we could not explain. Rare in Tahiti and extinct on other Society Islands, this species is common and widespread in the Marquesas.

Hurricanes have been suggested as extinction factors (Thibault and Guyot, 1987), but we were unable to find any evidence to support this.

One might also hypothesize that these isolated species could vanish because of inbreeding. This should not be discounted, but the

Table 4. The occurrence of flycatchers Pomarea spp. and rats on various islands in French Polynesia

\begin{tabular}{lccccccc}
\hline Species & Tahiti & Maupiti & $\begin{array}{l}\text { Nuku } \\
\text { Hiva }\end{array}$ & Hiva Oa & $\begin{array}{l}\text { Fatu } \\
\text { Hiva }\end{array}$ & Ua Pou & Motane Ua Huka \\
\hline $\begin{array}{l}\text { Flycatchers } \\
\text { Pomarea spp. }\end{array}$ & - & 0 & $0 ?$ & $0 ?$ & + & - & + \\
$\begin{array}{l}\text { Roof rat } \\
\text { Rattus rattus }\end{array}$ & + & + & + & + & 0 & + & 0 \\
\hline
\end{tabular}

+, abundant; -, rare; 0 , absent (or extinct when native birds). 


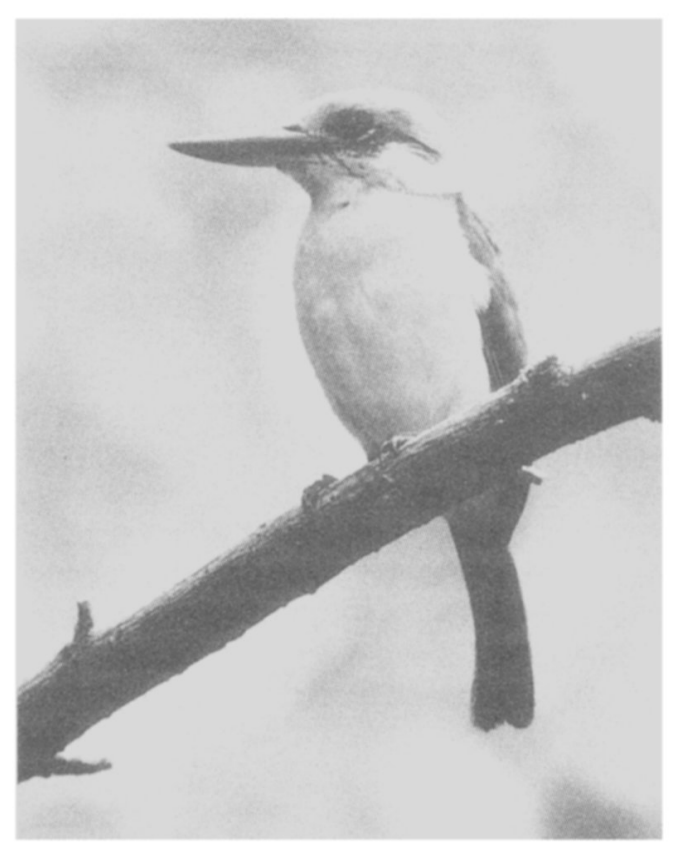

Halcyon gambieri gertrudae, a kingfisher now endemic to Niau (Roland Seitre).

history of a pair of Vini ultramarina, which was introduced during the 1940s to Ua Huka and which established a healthy population numbering at least 250 pairs today, suggests that genetic problems are not major factors for these species, which naturally originate from a small number of founders.

\section{Bird diseases}

It had been planned to collect small blood samples (without harming endemic birds) in order to look for parasites (malaria) and viruses (poxvirus), these having been recognized as direct causes of extinction for Hawaiian endemics (Jenkins et al., 1989). Unfortunately, we could not carry out this investigation because the local authorities did not grant the necessary permits.

During the field study we found no evidence to suggest that diseases were involved in declines or extinctions. Mosquitoes were present on all islands. Passerines, introduced as domestic birds, are basically the same from one island to another and we could find nothing to suggest that presence of passerine birds, which might carry disease, caused the disappearance of any native species. In the Hawaiian islands introduced mosquitoes, able to transmit diseases from migratory to native birds, were specifically identified as a major factor in declines and extinctions. The presence of these insects caused the extinction of many endemic landbirds, with birds surviving only at higher altitudes where mosquitoes do not occur. In French Polynesia birds retreat to higher altitudes to differing extents in the islands of any given archipelago. Further support for the view that mosquito-transmitted diseases are unlikely to be causes of declines comes from atolls, where bird distribution is fragmented while insect distribution is not, even though birds and insects can travel to all islets.

\section{Conclusion}

Ecological factors caused by man, especially rat introductions, are the principal causes of declines and extinctions of Polynesian landbirds. The outlook is therefore different from that in the Hawaiian islands, where diseases were the major problem, and more similar to the situation in New Zealand, where declines were due to the direct impact of man and introduced predators and where some species survive only on offshore islands. The conservation strategy has therefore more chance of success in French Polynesia: eradication techniques for introduced mammals have progressed well during the last decade (Moors, 1985; Veitch, 1985; Daly and Goriup, 1987; Thomas and Taylor, 1988; Taylor and Thomas, 1989). Once islands are free from introduced mammals, translocations of endemic birds to islands of the same group is recommended. Mohotani, once cleared of sheep and possibly cats, would be an excellent site for introduction of most Marquesas endemics.

\section{Acknowledgments}

Our expedition was self-financed but undertaken under the Museum National d'Histoire Naturelle (Paris), with the help of the French Navy (Marine Nationale), UTA and Air Tahiti. 


\section{References}

Atkinson I.A.E. 1985. Spread of commensal species of Rattus to oceanic islands and their effects on island avifaunas. In Conservation of Island Birds (ed. P. J. Moors), pp. 35-81. ICBP Technical Publication No. 3. ICBP, Cambridge.

Collar N.J. and Andrew P. 1988. Birds to Watch: The ICBP World Check-List of Threatened Birds. ICBP Technical Publication No. 8. ICBP, Cambridge.

Daly K. and Goriup P. 1987. Eradication of Feral Goats from Small Islands. ICBP Study Report No. 17. ICBP, Cambridge, 46pp.

Fuller E. 1987. Extinct Birds. Viking/Rainbird, London.

Garnett M.C. 1980. Management Plan for Nature Conservation in the Line and Phoenix islands, Part 1: Description. S.P.C. Nouméa.

Goodwin D. and Gillmor R. 1970. Pigeon and Doves of the World. British Museum, Cornell University Press, London.

Hay R. 1986. Bird Conservation in the Pacific Islands. ICBP Study Report No. 7. ICBP, Cambridge.

Holyoak D.T. 1975. Les oiseaux des Marquises, $L^{\prime}$ Oiseau et RFO. 45, 207-233, 341-366.

Holyoak D.T. and Thibault J.C. 1984. Contribution à l'étude des oiseaux de Polynésie Orientale. Mémoires du MNHN, Paris, 209pp.

Jenkins C.D., Temple S.A., Van Riper C. and Hansen W.R. 1989. Disease related aspects of conserving the endangered Hawaiian Crow. In Diseases and Threatened Birds (ed. J. E. Cooper), pp. 77-87. ICBP Technical Publication No. 10. ICBP, Cambridge.

Moors P.J. 1983. Predation by mustelids and rodents on eggs and chicks on natural and introduced birds in Kowhai Bush, New-Zealand. Ibis, 125, 137-154.

Moors P.J. 1985. Eradication campaigns against Rattus norvegicus on the Noises Islands, New Zealand, using Brodifacoum and 1080. In Conservation of Island Birds (ed. P. J. Moors), pp. 143-155. ICBP Technical Publication No. 3. ICBP, Cambridge.

Séchan Y. 1987. Lutte contre les rats en Polynésie française, dératisation de l'ilôt Teuaua, Ua Huka, Marquises, Note et Doc. d'Entomologie Médicale, ORSTOM Papeete No. 09, 37pp.

Seitre R. and Seitre J. 1991. Causes de disparition des oiseaux terrestres de Polynésie française. SPREP occasional paper series No. 8, South Pacific Commission, Nouméa, 92pp.

Sparrman A. 1953. A Voyage Round the World with Captain James Cook in HMS Resolution. Robert Hale Ltd, London.

Steadman D.W. 1989. Extinction of birds in Eastern Polynesia: a review of the records and comparisons with other Pacific Island Groups. Journal of Archaeological Science, 16, 177-205.

Taylor R.H. 1985. Status, habits and conservation of Cyanoramphus parakeet in the New Zealand region. In Conservation of Island Birds (ed. P. J. Moors), pp. 195-211. ICBP Technical Publication No. 3. ICBP, Cambridge.

Taylor R.H. and Thomas B.W. 1989. Eradication of Norway rats (Rattus norvegicus) from Hawea Island, Fiordland, using Brodifacoum. New Zealand Journal of Ecology, 12, 23-32.

Thibault J.-C. 1973. Remarques sus l'appauvrissement de l'avifaune polynésienne. Bull. Soc. Et. Oceaniennes, 15, 262-270.

Thibault J.-C. (ed.) 1988. Menaces et conservation des oiseaux de Polynésie française. In Livre Rouge des Oiseaux Menacés des Régions Françaises d'OutreMer. pp. 87-124. ICBP Monographie No. 5. ICBP, Cambridge.

Thibault J.-C. 1989. L'avifaune des îles Eiao et Hatuta'a (Polynésie, pacifique Sud): modifications intervenues au XXème siècle. L'Oiseau et la RFO, 59, 305-324.

Thibault J.-C. and Guyot I. 1987. Recent changes in the avifauna of Makatea Island (Tuamotu, Central Pacific). Atoll Research Bulletin, 300, 1-13.

Thibault J.-C. and Varney A. 1991. Numbers and habitat of the Rapa fruit-dove, Ptilinopus huttoni, Bird Conservation International, 1, 75-81.

Thomas B.W. and Taylor R.M. 1988. Rat eradication in Breaksea Sound. Forest and Bird, 19, 30-34.

Veitch C.R. 1985. Methods of eradicating feral cats from offshore islands in New-Zealand. In Conservation of Island Birds (ed. P. J. Moors), pp. 125-141. ICBP Technical Publication No. 3. ICBP, Cambridge.

Roland and Julia Seitre, Le Bourg, 37370 Marray, France. 